\title{
China boosts African research links
}

\section{Expanded programme of academic collaboration promised.}

Next week, representatives of dozens of African countries will gather in Beijing to firm up a broad programme of economic and scientific partnerships with China. It is the latest evidence that China's efforts to strengthen ties with Africa are increasingly focused on science and technology.

The Forum on China-Africa Cooperation (FOCAC) - which includes 49 African countries - will launch clean-energy projects, agricultural initiatives and training programmes. It will also see the inauguration of the ChinaAfrica joint research and exchange programme, which aims to set up research collaborations and academic visits between the partners.

China's government has not disclosed what it will spend on these plans, and its past efforts to boost African science have had mixed results. Many Western powers and some Africans are also wary of Chinese aid. "Its real intentions are well known: to elbow out all foreign companies and gain access to Africa's resources at cheap prices," said George Ayittey, a native of Ghana and an economist at American University in Washington DC, in an online debate in February sponsored by The Economist.

Chinese politicians counter that their goal is mutual benefit, and point to the tangible improvements that their partnership has already brought to African nations. According to China, an 'eight-step commitment' that was begun in 2006 has since given training to 15,000 professionals, including scientists. China has also started construction on 26 hospitals and completed 30 centres for the prevention and treatment of malaria, which offer drugs based on artemisinin, derived from a herb used in Chinese traditional medicine.

At FOCAC's fourth ministerial meeting, held in the Egyptian city of Sharm el-Sheikh in November 2009, China's Premier Wen Jiabao laid out a much more ambitious set of cooperative measures for the next three years (see 'Bold plans for Africa').

A planned network of agricultural technology centres will receive three years of financial and technical support to develop technologies relating to rice, fisheries or biomass, for example. Those that succeed in developing commercial products will get another five years of support from China. This mixture of aid and investment is a hybrid that explicitly tries to foster new business, says Deborah Brautigam, an international-development scholar at American

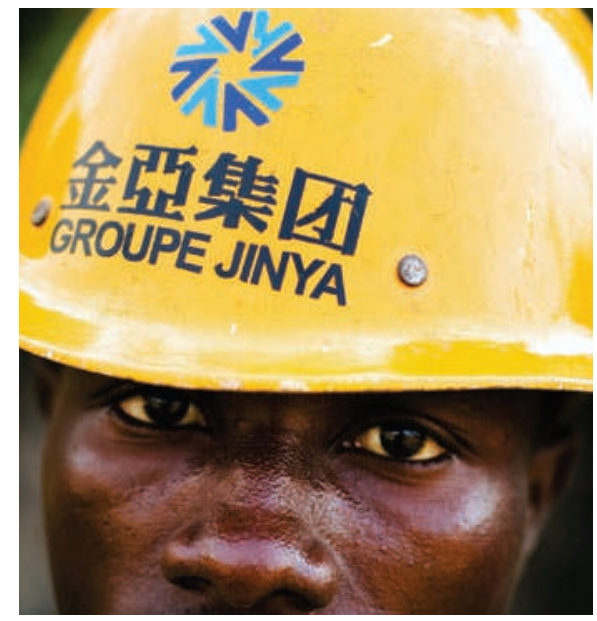

Is Africa benefiting from Chinese expertise?

University. “The Chinese government is hoping there will be a commercially oriented operation that would profit both sides."

\section{Promises, promises}

The goal of next week's meeting is to turn these promises into reality by fleshing out the details of how and when to implement each part of the proposed plan. "The track record of the Chinese government fulfilling its pledges towards Africa is strong, so I would anticipate the new pledges will be fulfilled," says Jing $\mathrm{Gu}$, a researcher at the non-profit Institute of

\section{Bold plans for Africa}

The Forum on China-Africa Cooperation plans to roll out a wide range of projects over the next three years.

- 100 clean-energy projects to combat climate change, including solar, biogas and hydroelectric power

- 100 science and technology demonstration projects

- 100 African postdoctoral students given funding to do research in China

- 20 agricultural technology demonstration centres

- 2,000 Africans trained in agricultural technology, including animal breeding, irrigation and fisheries management

- A joint research and exchange programme that aims to share development experience and provide intellectual support for African researchers

D.C.
Development Studies in Brighton, UK.

But some scientists in Africa say that past efforts have not been as successful as China claims. "China's visibility is very high in trade and business but quite low in science and technology," says Kazhila Chinsembu, a molecular biologist at the University of Namibia in Windhoek. Chris Whiteley, a enzymologist at Rhodes University in Grahamstown, South Africa, says that he has had a series of frustrating collaborations with Chinese researchers, and was unaware of FOCAC's efforts. Although his collaborations produced several research articles, Whiteley says that he often had to pay for his own trips despite being told that there would be funding available. "In my mind there are a lot of verbal promises but not much action," he says, adding that he is hopeful that new FOCAC commitments will improve the situation.

Other researchers argue that China's efforts aren't always tailored to Africa's needs. For example, China already sponsors long-term training programmes for African students, who move to China for several years, taking language courses while they study science in Chinese. Students see the experience as a good career move, but once they return to Africa, "the calibre of such scientists is very low", says Chinsembu, noting that the students struggle to assimilate scientific concepts in a foreign language. "Most cannot pass local examinations here in African universities."

Another problem, Chisenmbu says, is that once scientists return from China they are given no funding or equipment to put their training to work. "It is like the umbilical cord has been cut off," he says. He says that with more support, his university, which carries out research on traditional medicine, could benefit from China's experience. "I wish we could do more," he says.

Kenneth King, an African-studies specialist at the University of Edinburgh, UK, says that FOCAC's programme of short courses for African professionals is larger than that of any other nation except perhaps Japan. He estimates that science and technology subjects account for more than $60 \%$ of the courses under the eightstep commitment, and applauds the fact that they are conducted in English or French. King questions, however, how much good the short courses, which only run for one to two months, can achieve. "Is this form of short-term training exactly what African countries wanted?" he asks. "It is difficult to know."

David Cyranoski 